\title{
A skull of a very large crane from the late Miocene of Southern Germany, with notes on the phylogenetic interrelationships of extant Gruinae
}

\author{
Gerald Mayr ${ }^{1}$ [D $\cdot$ Thomas Lechner ${ }^{2} \cdot$ Madelaine Böhme $^{2}$
}

Received: 3 June 2020 / Revised: 1 July 2020 / Accepted: 2 July 2020 / Published online: 14 July 2020

(c) The Author(s) 2020

\begin{abstract}
We describe a partial skull of a very large crane from the early late Miocene (Tortonian) hominid locality Hammerschmiede in southern Germany, which is the oldest fossil record of the Gruinae (true cranes). The fossil exhibits an unusual preservation in that only the dorsal portions of the neurocranium and beak are preserved. Even though it is, therefore, very fragmentary, two morphological characteristics are striking and of paleobiological significance: its large size and the very long beak. The fossil is from a species the size of the largest extant cranes and represents the earliest record of a large-sized crane in Europe. Overall, the specimen resembles the skull of the extant, very long-beaked Siberian Crane, Leucogeranus leucogeranus, but its affinities within Gruinae cannot be determined owing to the incomplete preservation. Judging from its size, the fossil may possibly belong to the very large "Grus" pentelici, which stems from temporally and geographically proximate sites. The long beak of the Hammerschmiede crane conforms to an open freshwater paleohabitat, which prevailed at the locality.
\end{abstract}

Keywords Aves $\cdot$ Evolution $\cdot$ Gruidae $\cdot$ Systematics $\cdot$ Tortonian

\section{Zusammenfassung}

Ein Schädel eines sehr großen Kranichs aus dem Obermiozän Süddeutschlands, mit Bemerkungen zu den Verwandtschaftsbeziehungen heutiger Gruinae

Wir beschreiben einen partiell erhaltenen Schädel eines sehr großen Kranichs aus dem frühen Obermiozän (Tortonium) der Hominiden-Fundstelle Hammerschmiede in Süddeutschland, welcher den ältesten Fossilnachweis der Gruinae (echte Kraniche) repräsentiert. Der Fund weist eine ungewöhnliche Erhaltung auf, da nur die dorsalen Bereiche des Hirnschädels und des Schnabels erhalten sind. Obwohl das Fossil daher sehr fragmentarisch ist, sind zwei morphologische Merkmale auffällig und von paläobiologischer Bedeutung: seine Größe und der sehr lange Schnabel. Der fossile Schädel stammt von einer Art von der Größe der größten heutigen Kraniche und ist der früheste Nachweis eines derart großen Kranichs in Europa. Insgesamt ähnelt das Fossil dem Schädel des heutigen, sehr langschnäbeligen Sibirischen Kranichs, Leucogeranus leucogeranus, aber seine Verwandtschaftsbeziehungen innerhalb der Gruinae können aufgrund der unvollständigen Erhaltung nicht bestimmt werden. Die Körpergröße legt nahe, dass der Fund möglicherweise zu der sehr großen Art "Grus" pentelici gehört, die von zeitlich und geographisch nahen Fundstellen stammt. Der lange Schnabel des Hammerschmiede-Kranichs steht im Einklang mit einem offenen Süßwasser-Paläohabitat, das vor Ort vorherrschte.

Communicated by F. Bairlein.

Gerald Mayr

Gerald.Mayr@senckenberg.de

1 Ornithological Section, Senckenberg Research Institute and Natural History Museum Frankfurt, Senckenberganlage 25, 60325 Frankfurt am Main, Germany

2 Senckenberg Center for Human Evolution and Paleoecology (HEP), Institute for Geoscience, Eberhard-Karls University Tübingen, Sigwartstr. 10, 72076 Tübingen, Germany

\section{Introduction}

Cranes (Gruidae) today include 15 species of long-necked and long-legged birds, which occur in open habitats of all Old World continents and North America (Archibald and Meine 1996). Extant Gruidae are subdivided into the sister taxa Balearicinae (crowned cranes; today only represented by two African species of the taxon Balearica) and Gruinae (true cranes; all other extant species). Gruidae form a 
clade (Gruoidea) together with the New World Aramidae (limpkins) and Psophiidae (trumpeters), and their evolution appears to have been correlated with the Neogene spread of grasslands.

The fossil record of the Gruidae is not very extensive, and many species are based on fragmentary bones of uncertain affinities (Cracraft 1973; Mourer-Chauviré 2001; Mlíkovský 2002; Göhlich 2003; Mayr 2009, 2017; Zelenkov 2015). The taxonomy of many fossil cranes is also in need of a revision, because the type species of various widely used genus-level taxa introduced by Lambrecht (1933) do not belong to the Gruidae. This is true, for example, for the taxon Palaeogrus Lambrecht, 1933, which was originally established for Palaeogrus princeps from the middle Eocene of Italy (Portis 1885). This species is only known from a distal tibiotarsus and was long regarded as the earliest record of the Gruidae, but is more likely to be a representative of the palaeognathous Palaeotididae (Mayr 2019).

Irrespective of taxonomic issues, the affinities of most Eocene fossils assigned to the Gruidae (Mayr 2009) are not well established. Eobalearica tugarinovi from the middle Eocene of Uzbeskistan, for example, was hypothesized to possibly belong to the Pelagornithidae (bony-toothed birds; Mayr and Zvonok 2011), even though Zelenkov and Kurochkin (2015) maintained affinities to the Gruidae. A putative gruiform bird from the late Eocene and early Oligocene of England, Geranopsis hastingsiae, may belong to the Parvigruidae, which are stem group representative of the Gruoidea from the early Oligocene of Europe (Mayr 2005, 2012).

Several Paleogene and early Neogene species of the Gruidae were assigned to Palaeogrus, but this classification can no longer be upheld in light of the likely palaeotidid affinities of $P$. princeps, the type species of the taxon. Moreover, the significant time interval between these fossils and the middle Eocene type species makes an assignment to the same genus highly unlikely. "Palaeogrus" hordwelliensis from the late Eocene of England is only known from the distal end of the tibiotarsus (Lydekker 1891). "P." excelsa from the early Miocene of France is better represented by various postcranial bones, but its genus-level assignment is likewise in need of a revision. This is also true for "Palaeogrus" mainburgensis from the middle Miocene of Germany (Göhlich 2003), which is a small species that differs from extant Gruidae in hypotarsus morphology (a tentatively referred coracoid appears to be too small to belong to this species and may be from a larger species of the Anseriformes). "P." mainburgensis is of similar size to Basityto rummeli from the early Miocene of Germany and there exists a possibility that both species are closely related, if not conspecific. In this case the taxon Basityto may encompass some of the early and middle Miocene cranes from Europe, which is unfortunate, since this name reflects the initial misidentification of $B$. rummeli as a tytonid owl (Mlíkovský 1998; Mourer-Chauviré 2001).

"Palaeogrus" excelsa was assigned to the Balearicinae (as "Balearica excelsa") by Mlíkovský (2002), and Basityto rummeli was likewise transferred to Balearica by MourerChauviré (2001). However, the characters in support of these classifications may well be plesiomorphic for the Gruidae. Other Paleogene and early Neogene fossils were likewise assigned to the Balearicinae, but again the taxonomy and phylogenetic affinities of some of the involved species is problematic. The taxon Probalearica, for example, was established by Lambrecht (1933) for P. problematica, a species from the early Miocene of France based on a fragmentary upper beak, which is now assigned to the phoenicopteriform Palaelodidae (Cheneval and Escuillié 1992). "Probalearica" moldavica from the late Miocene of Moldova was assigned to the Gruinae by Mlíkovský (2002), but this species is not a crane (Mourer-Chauviré 2001) and may actually be a heron (Ardeidae; Zelenkov 2015).

Putative Balearicinae were also reported from the Miocene of North America (Olson 1985; Olson and Rasmussen 2001). One of these, "Probalearica" crataegensis from the early Miocene of Florida, is based on the distal end of a tibiotarsus (Brodkorb 1963). Olson (1985) also considered the putative limpkin Aramornis longurio from the early/middle Miocene of Nebraska to be a representative of the Balearicinae; the holotype and only known specimen of this species is a distal tarsometatarsus. Another species, Balearica exigua from the late Miocene of Nebraska, is represented by well-preserved skeletons (Feduccia and Voorhies 1992), but meaningful comparisons between B. exigua, "P." crataegensis, and A. longurio have yet to be performed.

Göhlich (2003) listed "Grus" miocenicus as the earliest record of the Gruinae, but this species, which stems from the late middle Miocene of Romania (Grigorescu and Kessler 1977), is also a misidentified record of the Palaelodidae (Mlíkovský 2002). One of the earliest described fossil species of the Gruinae is, therefore, "Grus" pentelici, which was first reported from the late Miocene of Greece (see Cracraft 1973; Mlíkovský 2002). The species has also been identified in the late Miocene of Hungary (Kretzoi 1957) and the middle Miocene of Sansan in France (Depéret 1887), but especially the latter record is very fragmentary and was not listed in a recent revision of the locality (Cheneval 2000). "Grus" pentelici was assigned to the taxon Pliogrus by Lambrecht (1933), which was established for Pliogrus germanicus from the middle to late Miocene of Eppelsheim in Germany (the fossiliferous sediments of this fluvial site were deposited between 15 and $9 \mathrm{Ma}$; Böhme et al. 2012). However, this latter species, which is only known from a distal tibiotarsus, is much smaller than " $G$." pentelici and was transferred to the Palaelodidae (Fischer and Stephan 1971; Mlíkovský 
2002). "G." pentelici was a very large species, the size of the extant Grus antigone and Bugeranus carunculatus. An equally large-sized species, "Grus" afghana from the late Miocene of Afghanistan (Mourer-Chauviré et al. 1985), was regarded as a junior synonym of "G." pentelici by Mlíkovský (2002).

"Probalearica" mongolica from the late Miocene and early Pliocene of Mongolia (Zelenkov 2013) is another large-sized crane, which is only known from a distal tibiotarsus. The species was assigned to the taxon Grus (sensu lato), as G. mongolica, by Zelenkov (2013), who also noted similarities to Leucogeranus. A distinctive, small-sized species of crane, Camusia quintanai, inhabited the Balearic island of Menorca during the Pliocene and was considered to occupy a basal phylogenetic position within the Gruinae (Seguí 2002).

During the Pleistocene, a very large crane, "Grus" melitensis, occurred on the Mediterranean islands of Malta and Sicily (Lydekker 1890, 1891; Northcote 1982a; Pavia and Insacco 2013). Another large species, "Grus" primigenia, was found in Pleistocene localities of the Mediterranean area, including the Balearic island of Majorca, and in the Holocene of Northern Europe (Northcote and MourerChauviré 1985, 1988; Mlíkovský 2002; Stewart 2007). The taxonomic status of "G." primigenia was controversially discussed and some authors considered it to be conspecific with the extant G. antigone or G. grus (see Stewart 2007). Mlíkovský (2002) synonymized "G." melitensis and "G." bohatshevi from the Pleistocene of Azerbaijan with " $G$." primigenia, but this taxonomic action was poorly founded and only based on the large size of the involved species.

Outside Europe, a Grus antigone-sized crane coexisted with smaller species of the Gruidae in the early Pliocene of North Carolina (Olson and Rasmussen 2001). Large-sized cranes were furthermore reported from the Pleistocene of Florida (Emslie 1995) and Cuba (Grus cubensis; Fischer and Stephan 1971).

Here we describe a partial skull of a very large crane from the German locality Hammerschmiede near Pforzen (Allgäu region, Bavaria). The fossiliferous sediments of this clay pit stem from the earliest late Miocene (Tortonian; MN 8) and were deposited in a fluvio-alluvial flood plain. The vertebrate fauna of the Hammerschmiede locality is very diverse and includes more than 120 species, including the bipedal hominid Danuvius guggenmosi (Böhme et al. 2019). So far, the only formally described bird species is the darter Anhinga pannonica (Anhingidae; Mayr et al. 2020), but there exists a fairly rich record of undescribed avian remains, which belong to waterfowl (Anseriformes), cormorants (Phalacrocoracidae), landfowl (Galliformes), diurnal birds of prey (Accipitridae), Passeriformes (passerines), and Alcedinidae (kingfishers). The crane skull described in the present study is the oldest fossil record of the Gruinae and expands the known temporal range for the occurrence of large-sized cranes in Europe.

\section{Materials and methods}

The fossil is deposited in the paleontological collection of the University of Tübingen, Germany (GPIT). Comparisons with extant species are based on the osteological collection of the ornithological section of Senckenberg Research Institute Frankfurt (SMF), which includes skulls of the following species of the Gruidae (the taxonomy follows Krajewski et al. 2010; the different genus-level classification employed by the IOC World Bird List [https://www.worldbirdnames. org] is indicated in parentheses): Balearica balearica, $B$. pavonina, Leucogeranus leucogeranus, Bugeranus (Grus) carunculatus, Anthropoides (Grus) paradisea, A. (G.) virgo, Grus (Antigone) antigone, G. (Antigone) vipio, G. (Antigone) rubicunda, Grus grus, G. japonensis, and G. nigricollis. Comparisons with Grus (Antigone) canadensis are based on a trunk skeleton in SMF and the synoptic skeleton images provided by the Smithsonian National Museum of Natural History at https://collections.nmnh.si.edu/search/birds.

\section{Systematic palaeontology}

\author{
Gruiformes Bonaparte, 1854. \\ Gruidae Vigors, 1825. \\ Gen. et sp. indet.
}

\section{Referred specimen}

GPIT/AV/00196: dorsal portion of skull (Fig. 1); found in the 2019 excavation season in the local stratigraphic horizon HAM 4.

\section{Stratigraphic horizon}

The fossil stems from the local stratigraphic horizon Hammerschmiede 4 (HAM 4), about six meters above the hominid-bearing level HAM 5 (Böhme et al. 2019). The fossiliferous sediments of HAM 4 originated in a river of about $50 \mathrm{~m}$ width, and vertebrate fossils accumulated in channellag deposits between 11.59 and 11.44 million years ago (Kirscher et al. 2016). 


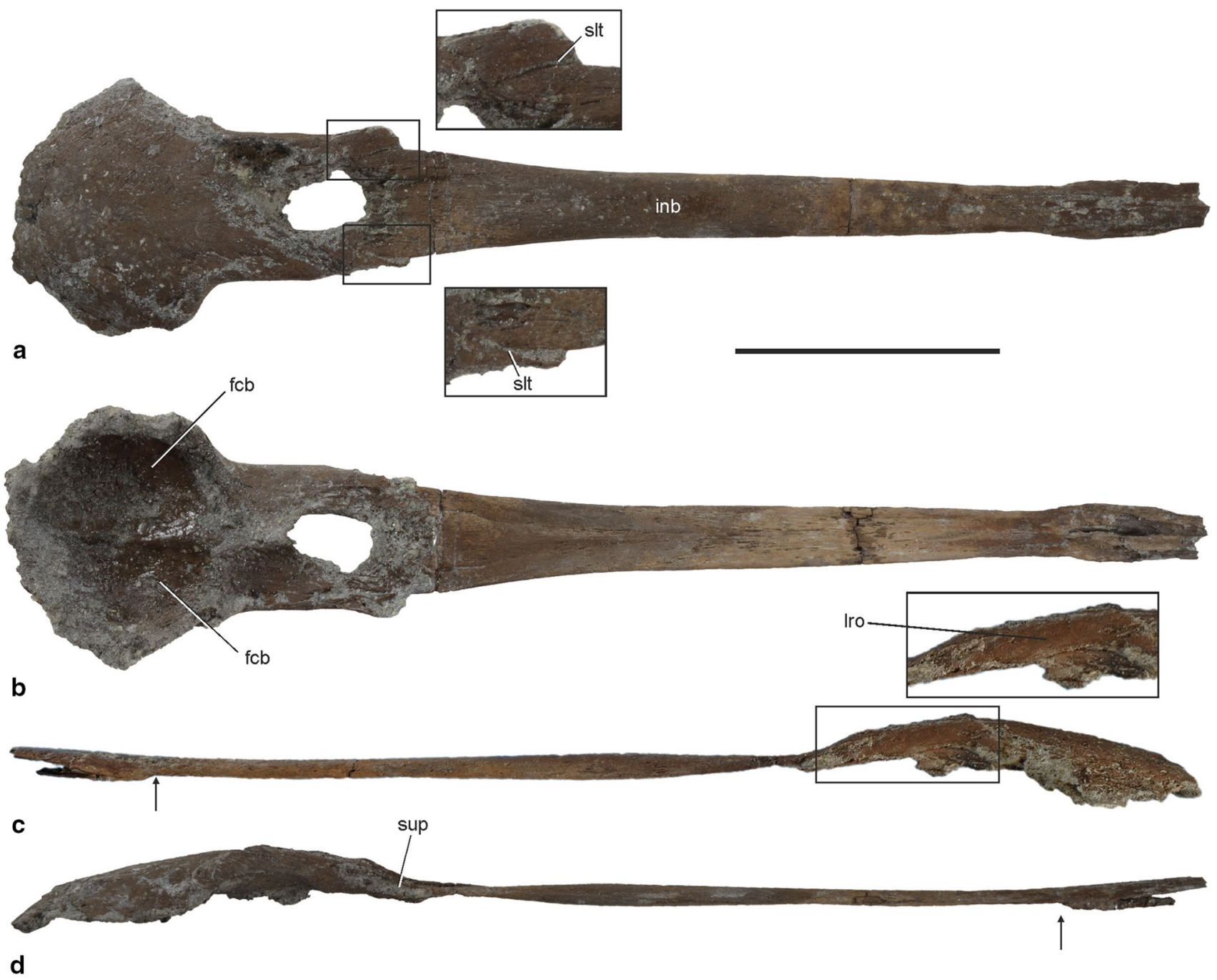

Fig. 1 Skull fragment of a large crane from the early late Miocene of the Hammerschmiede locality in southern Germany (GPIT/ AV/00196). a Dorsal view. b Ventral view. c Left lateral view. d Right lateral view. The frames in $\mathbf{a}$ and $\mathbf{c}$ indicate the position of the

\section{Measurements (in $\mathrm{mm}$ )}

Length as preserved, 225.9; length of nostril, 122.0; estimated total skull length, $\sim 265$.

\section{Taphonomic remarks}

The fossil skull shows a highly unusual preservation in that only the dorsal portions of the beak and neurocranium are preserved (Fig. 2j). The specimen was discovered in situ in undisturbed sediment. Therefore, we exclude the possibility that it was damaged in the course of the excavation or due to mining activities in the clay pit. Attached sediment along the breaking edges suggests that the damage occurred before the final deposition of the fossil. details shown aside. The arrows in $\mathbf{c}$ and $\mathbf{d}$ denote the end of the nostril. $f c b$ fossa cerebelli, inb internarial bar, lro lateral rim of orbit, slt slit-like caudal end of nostril, sup articulation site of supraorbital process. Scale bar: $50 \mathrm{~mm}$ [Color online].

To the best of our knowledge, no other fossil bird skull has been described that shows a similar preservation. The most common damage of bird skulls concerns a breakage of the beak at the nasofrontal hinge, whereas the cranium usually remains intact. At the excavation site, the damaged ventral surface of the specimen was facing upwards, so that the skull was embedded in the sediment with its dorsal surface down.

So far, the specimen represents the only avian skull from the Hammerschmiede locality. The HAM 4 layer represents fluvial river channel deposits, and the fossils frequently exhibit signs of reworking and sorting. GPIT/AV/00196 lacks most of the ventral portion and the skull may, therefore, have been fixed in the sediment and may have been partly exposed, when a destructive event chopped its ventral 


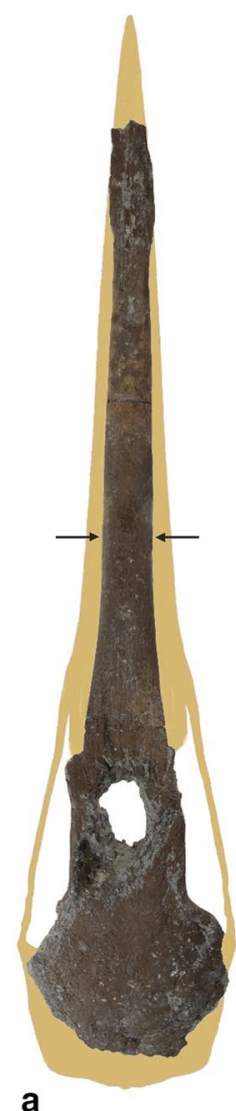

a

b

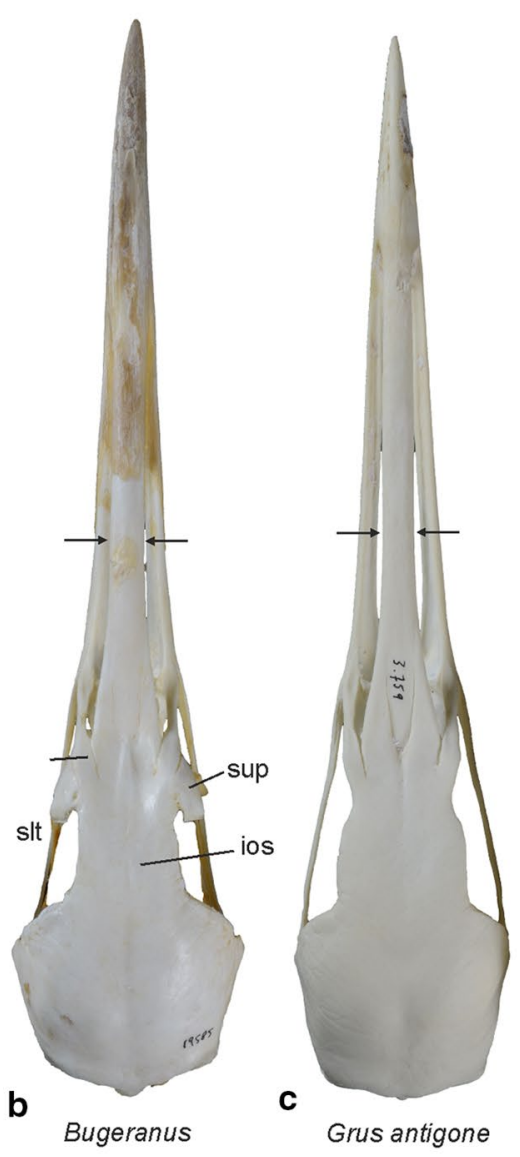

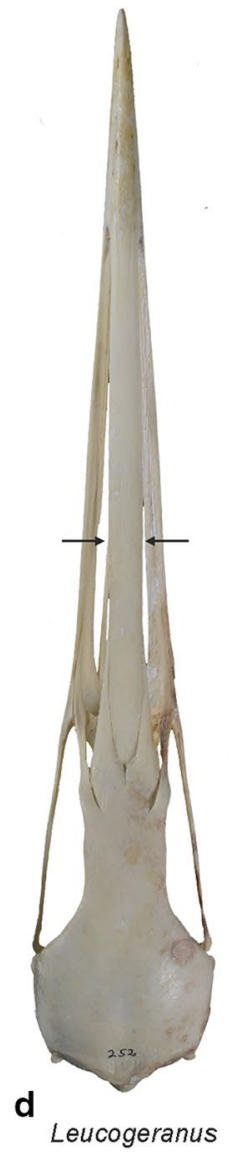

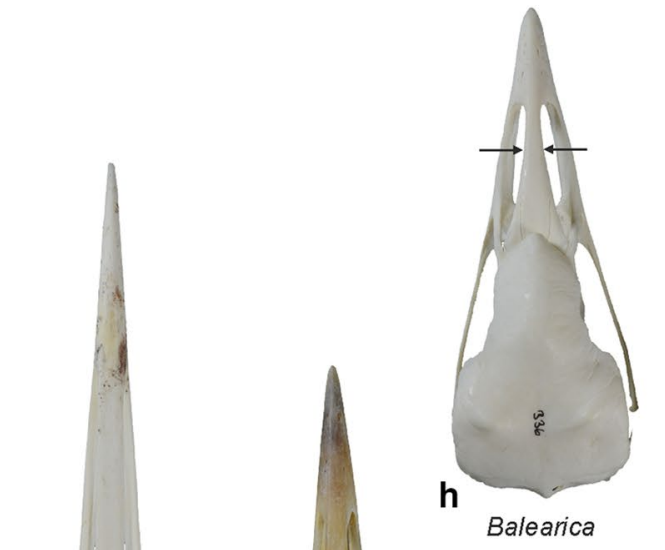

e

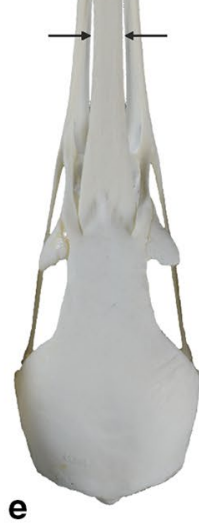

Grus vipio
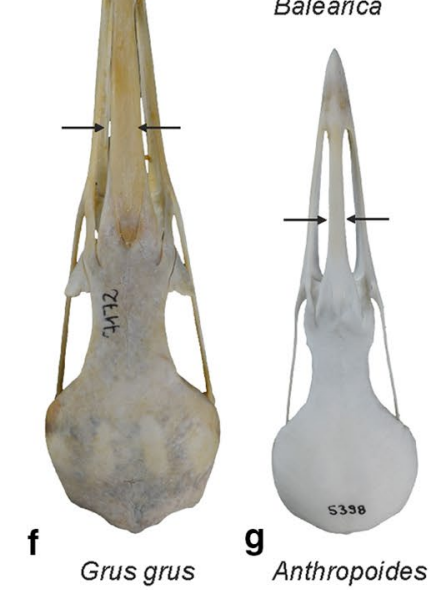

Anthropoides

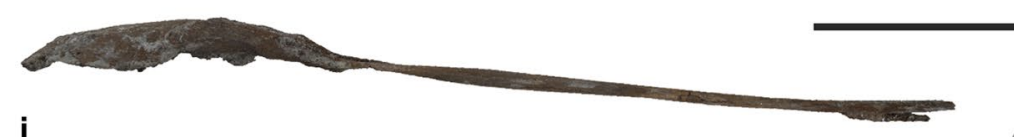

i

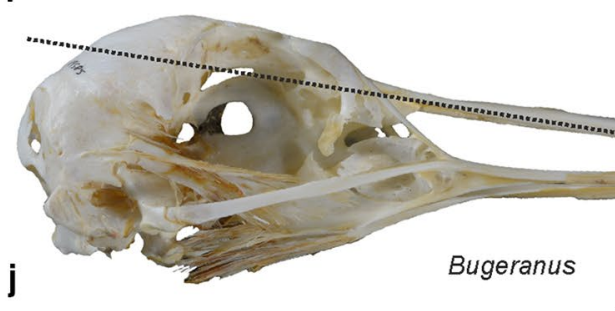

m

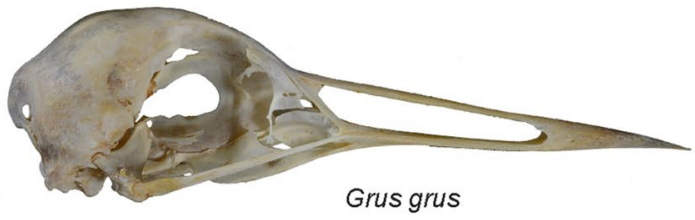

Grus grus

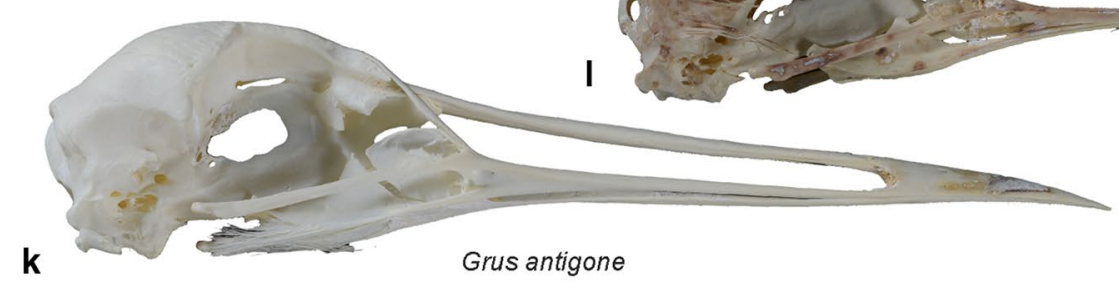

\section{Leucogeranus}

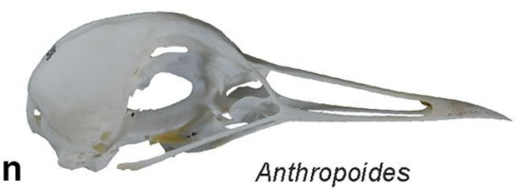

Fig. 2 Skulls of the Hammerschmiede crane and extant Gruidae in dorsal (a-h) and lateral (i-n) view. a, i the fossil Hammerschmiede crane (the silhouette indicates the reconstructed outline). b, j Bugeranus carunculatus (SMF 19585). c, $\mathbf{k}$ Grus antigone (SMF 3759). d, $\mathbf{l}$ Leucogeranus leucogeranus (SMF 252). e Grus vipio (SMF 11375).f,

m Grus grus (SMF 7172). g, n Anthropoides virgo (SMF 5398). h Balearica regulorum (SMF 336). The arrows in $\mathbf{a}-\mathbf{h}$ denote the width of the internarial bar. The dotted line in $\mathbf{j}$ indicates the level the skull was cut in the fossil. ios interorbital section, slt slit-like caudal end of nostril, sup supraorbital process. Scale bar: $50 \mathrm{~mm}$ [Color online]. 
portion. The excavation area directly surrounding the fossil contained turtle and mammal bones of comparable density and elongate shape, which indicates that the skull was deposited along other bones with similar properties.

\section{Description and comparisons}

The very long and straight bill lacks the tip, but is of similar relative length to that of the extant Bugeranus carunculatus (Fig. 2b) and Leucogeranus leucogeranus (Fig. 2d), which are among the extant cranes with the proportionally longest beaks (Table 1).

The nostrils are very long and exhibit a schizorhinal condition, with a slit-like caudal end that extends beyond the nasofrontal hinge. A notable feature is the broad internarial bar, which is proportionally wider than in all extant cranes and almost twice as wide as that of the similar-sized B. carunculatus (Fig. 2). The fossil shows little compression, so that we do not consider this unusually wide internarial bar to be an artefact of a taphonomic flattening. The entire ventral surface of the internarial bar has a flat, unstructured surface without any traces of an ossified internarial septum. On the dorsal surface, the base of the internarial bar exhibits a shallow fossa, which is also present in extant cranes.

A distinctive feature of the fossil is the dorsoventrally thickened lateral rim of orbit (Fig. 1c), which characterizes all modern cranes except for B. carunculatus. Unlike in extant Gruidae, there is no noticeable notch for the processus supraorbitalis in the orbital rim. The interorbital section of the frontal bones is wide as in most extant cranes (an exception is Grus japonensis, in which the interorbital section is proportionally narrower).
The dorsal surface of the neurocranium is only slightly elevated relative to the beak and does not form a marked vault. The dorsal surface of the neurocranium exhibits vascular furrows. There is no dorsal midline fossa on top of the neurocranium. On the ventral surface, the fossae cerebelli for the two cerebral hemispheres of the telencephalon are visible.

\section{Phylogenetic interrelationships of the Gruinae- molecular data and sternum morphology}

The interrelationships of cranes have been studied based on DNA-DNA hybridization and mitochondrial sequence data (Krajewski 1989; Krajewski and Dickerman 1990; Krajewski and Fetzner 1994; Krajewski et al. 2010). These analyses support the long-assumed split between Balearicinae and Gruinae, but suggest paraphyly of the traditional (e.g., Archibald and Meine 1996) taxon Grus. Not only is the Siberian Crane, Leucogeranus leucogeranus, recovered as the sister taxon of all other Gruinae, but a clade including Grus antigone, G. vipio, G. rubicunda, and G. canadensis is found to be the sister taxon of a clade including the sister taxa Bugeranus and Anthropoides as well as the other species of Grus (Fig. 3a; Krajewski et al. 2010). However, as yet no nuclear sequence data have been published and the trees based on DNA-DNA hybridization and mitochondrial sequences conflict with morphological evidence and sternum morphology in particular, which shows considerable variation in the Gruidae.

An account of the sternum morphology of the Gruidae was already given by Stephan and Fischer (1971), but the existing variation has not yet been set in context with the results of molecular phylogenies. The sternum of the

Table 1 Skull dimensions of the Hammerschmiede crane and extant species of the Gruidae (in mm; the length of the upper beak was measured from the tip to the caudal end of the processus frontalis of the os nasale)

\begin{tabular}{lllr}
\hline & Skull length & Beak length & $\begin{array}{l}\text { Ratio beak: skull } \\
\text { (mean values) }\end{array}$ \\
\hline Hammerschmiede crane & $\sim 265$ [est.] & $\sim 195[$ est. $]$ & $\sim 0.73$ \\
Balearica pavonina & $113.6-123.7[n=4](\bar{x}=119.4 \pm 3.9)$ & $58.3-64.6[n=4](\bar{x}=61.9 \pm 2.5)$ & 0.52 \\
B. regulorum & $112.0-124.0[n=4](\bar{x}=119.4 \pm 5.0)$ & $54.9-67.0[n=4](\bar{x}=62.5 \pm 4.8)$ & 0.52 \\
Leucogeranus leucogeranus & $259.5-268.5[n=2](\bar{x}=264.0 \pm 4.5)$ & $187.6-192.1[n=2](\bar{x}=189.9 \pm 2.3)$ & 0.72 \\
Anthropoides virgo & $120.4-136.7[n=6](\bar{x}=126.3 \pm 5.3)$ & $68.5-80.7[n=6](\bar{x}=72.7 \pm 4.1)$ & 0.58 \\
A. paradisea & $150.2-163.0[n=4](\bar{x}=157.7 \pm 4.8)$ & $86.8-98.0[n=4](\bar{x}=94.0 \pm 4.4)$ & 0.60 \\
Bugeranus carunculatus & $259.3[n=1]$ & $176.9[n=1]$ & 0.68 \\
Grus antigone & $224.3-256.7[n=4](\bar{x}=238.5 \pm 12.2)$ & $150.8-175.8[n=4](\bar{x}=162.6 \pm 9.1)$ & 0.68 \\
G. vipio & $209.6-226.2[n=4](\bar{x}=217.2 \pm 6.4)$ & $145.5-149.5[n=4](\bar{x}=147.1 \pm 1.5)$ & 0.68 \\
G. rubicunda & $203.0[n=1]$ & $137.5[n=1]$ & 0.68 \\
G. grus & $163.1-181.4[n=6](\bar{x}=169.6 \pm 6.1)$ & $99.5-108.0[n=6](\bar{x}=103.2 \pm 3.4)$ & 0.61 \\
G. nigricollis & $194.7[n=1]$ & $128.5[n=1]$ & 0.66 \\
G. japonensis & $228.9-232.4[n=2](\bar{x}=230.7 \pm 1.75)$ & $156.3-160.5[n=2](\bar{x}=158.4 \pm 2.17)$ & 0.69 \\
\hline
\end{tabular}




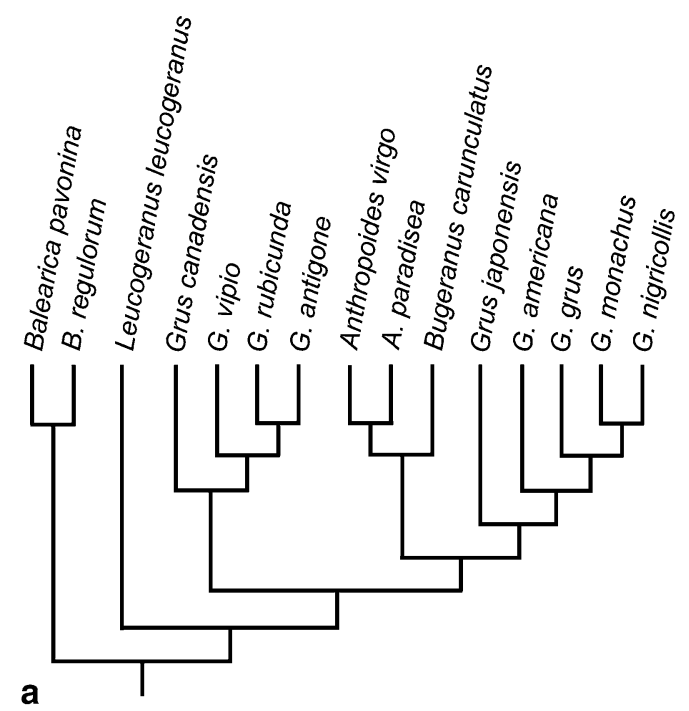

Fig. 3 Interrelationships of extant cranes based on analysis of molecular data contrasted with a modified phylogeny that takes differences in sternum morphology into account. a molecular phylogeny of Kra-

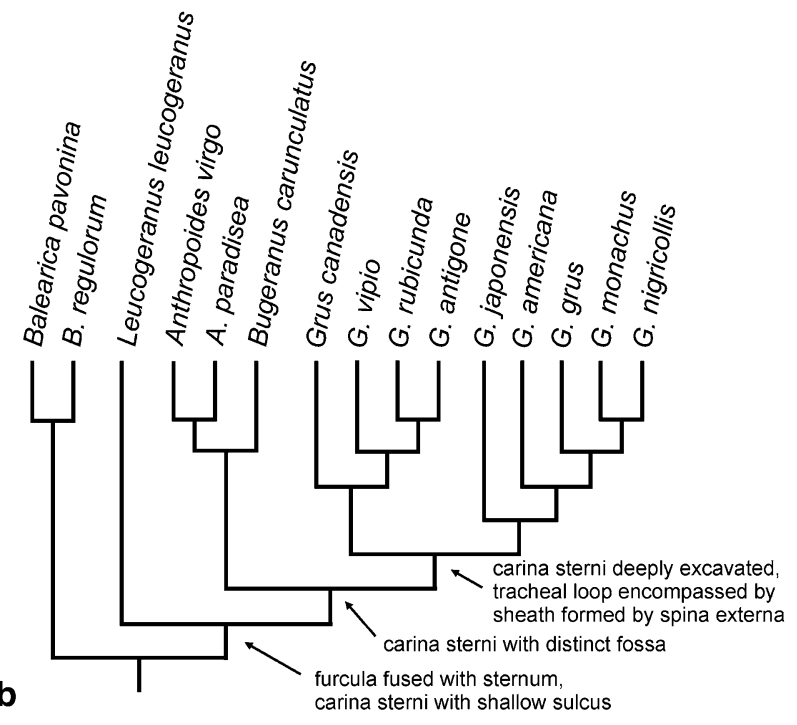

jewski et al. (2010) based on complete mitochondrial sequences. b modified phylogeny based on sternum morphology; apomorphies are listed at the nodes (see text)
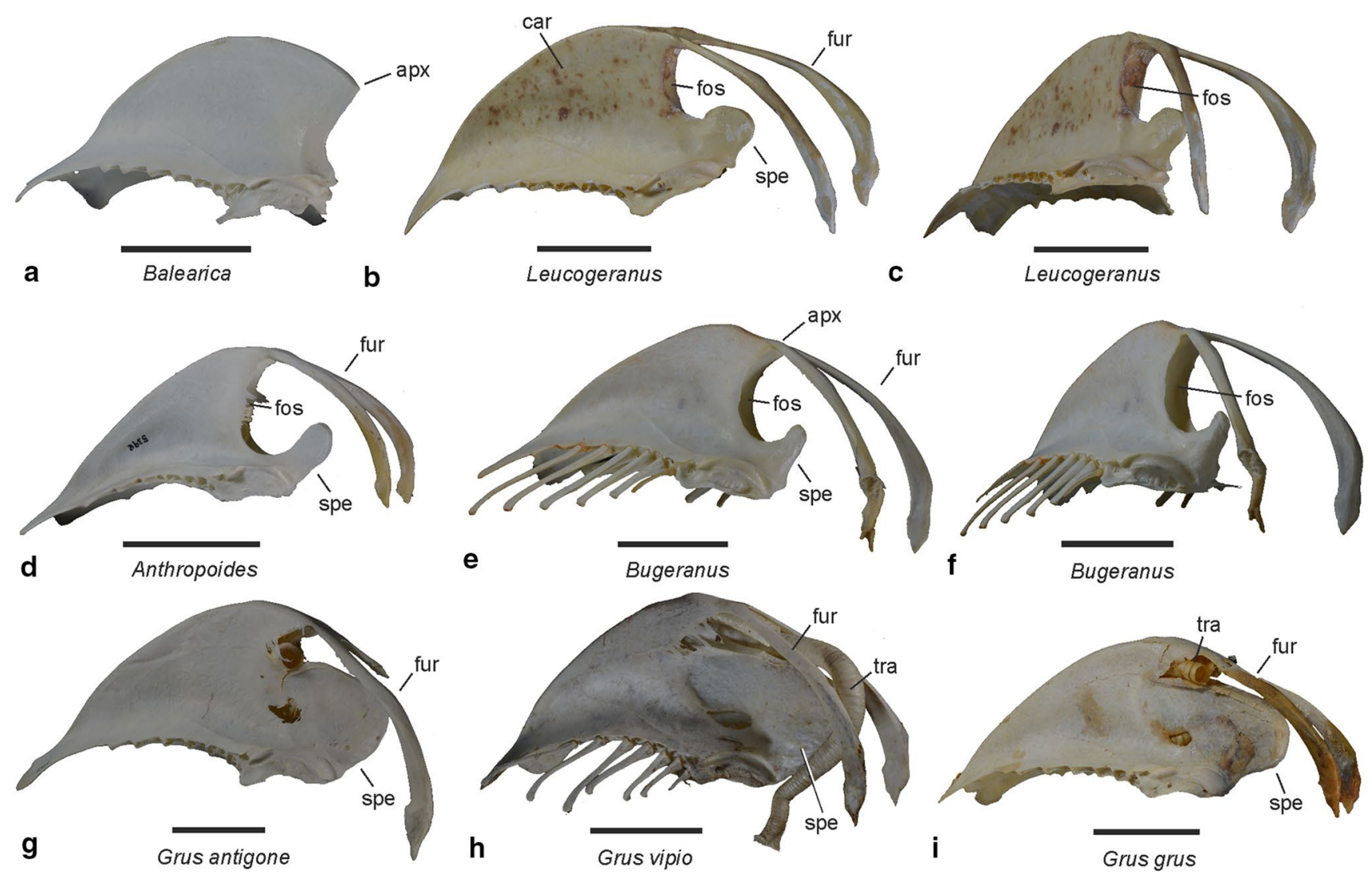

Fig. 4 Sternum of extant Gruidae in left lateral view to show variation in the osteological structures encompassing the trachea. a Balearica regulorum (SMF 336). b, c Leucogeranus leucogeranus (SMF 252) in b lateral and $\mathbf{c}$ craniolateral view. d Anthropoides virgo (SMF 5398). e, f Bugeranus carunculatus (SMF 8599) in e lat- eral and f craniolateral view. g Grus antigone (SMF 3759). h Grus vipio (SMF 11375; right side, mirrored). i Grus grus (SMF 7172). apx apex carinae, car carina sterni, fos fossa encompassing trachea, fur furcula, spe spina externa, tra trachea. Scale bars: $50 \mathrm{~mm}$ [Color online]. 
Balearicinae (Fig. 4a) still resembles that of the Aramidae, the sister taxon of the Gruidae, in that there is no spina externa, the furcula is not co-ossified with the apex carinae, and the trachea is not coiled, with the tracheal loop not being encompassed by the carina sterni. In all Gruinae, by contrast, a well-developed spina externa is present, the furcula is coossified with the apex carinae, and the cranial margin of the carina sterni braces or encompasses a tracheal loop.

Amongst the Gruinae, the least specialized sternum morphology is present in Leucogeranus, in which the cranial margin of the carina bears only a shallow fossa for the tracheal loop (Fig. 4b, c). In Anthropoides spp. (Fig. 4d) and Bugeranus (Fig. 4e, f), the fossa in the cranial margin of the carina sterni is much more marked than in Leucogeranus and forms a deep excavation. In all other examined species of Grus (Grus antigone (Fig. 4g), G. canadensis, G. vipio (Fig. 4h), G. grus (Fig. 4i), G. nigricollis, and G. japonensis), the tracheal loop is encompassed by a marked cavity formed by the cranial portion of the carina sterni and the trachea extends further caudally within the carina sterni; the cranial margin of the carina and the spina externa furthermore form a sheath, which fully encompasses the tracheal loop. In G. grus, G. nigricollis, and G. japonensis, which form a clade in molecular phylogenies (Fig. 3a), the tracheal loop extends deep into the carina and reaches almost to the caudal end of the sternum; as a consequence, the carina is much wider mediolaterally, and the dorsal surface of the sternum (pars hepatica) shows a distinct longitudinal bulge in its caudal section.

Whereas sternum morphology supports an early divergence of the taxon Leucogeranus, it conflicts with molecular data concerning the affinities of Anthropoides and Bugeranus. In molecular phylogenies, these latter two taxa are nested within a clade together with Grus antigone, $G$. canadensis, G. vipio, G. grus, G. nigricollis, and G. japonensis (Fig. 3a), but sternum morphology supports the traditional view that Anthropoides and Bugeranus are the sister taxon of this clade (Fig. 3b).

\section{Discussion}

\section{Identification, taxonomic identity, and phylogenetic affinities}

Although GPIT/AV/00196 is very fragmentary, the fossil can be unambiguously assigned to the Gruidae based on a number of derived characteristics, including schizorhinal nostrils (which are absent in the equally long-beaked Ciconiidae and Ardeidae), a wide interorbital section of the frontal bones, a dorsoventrally thickened lateral margin of the orbital rim, and vascular furrows on the dorsal surface of the neurocranium. The very long beak of the Hammerschmiede crane suggests its classification into the Gruinae, but meaningful comparisons with the dorsal portion of the neurocranium of the Balearicinae are hindered by the fact that the corresponding skull section is greatly modified in crowned cranes and exhibits a highly apomorphic morphology. The specimen represents the largest bird as yet reported from the Hammerschmiede locality and no postcranial remains of an equally-sized bird could as yet be identified in the avian material from the site.

The tallest extant Gruidae are the African Wattled Crane, Bugeranus carunculatus, and the Australasian Sarus Crane, Grus antigone, both of which reach a standing height of about $175 \mathrm{~cm}$ (Archibald and Meine 1996). With an estimated total skull length of about $265 \mathrm{~mm}$, the fossil reaches the skull length of these two extant species and that of the long-beaked but somewhat smaller Siberian Crane, Leucogeranus leucogeranus (Fig. 2; Table 1).

The crane from the Hammerschmiede clay pit is much larger than all species assigned to "Palaeogrus". Judging from its very large size, it may possibly belong to the large "Grus" pentelici (Cracraft 1973; Mlíkovský 2002), which stems from temporally and geographically proximate sites. Of "G." pentelici no skull has been found, but the dimensions of the postcranial bones indicate a species about the size of $G$. antigone. The Hammerschmiede fossil is, however, more than four million years older than the fossils of $G$. pentelici from the Greek type locality Pikermi, the fossiliferous strata of which are dated to $7.33 \mathrm{Ma}$ (MN 12; Böhme et al. 2017). If the crane from Csakvar in Hungary (MN11; Kretzoi 1957) was correctly assigned to "G." pentelici, the species would already have been present in Europe 8-9 Ma. Other large-sized fossil cranes, that is, "G." afghana (MN 12; Mlíkovský 2002) and "G." mongolica (MN 13/MN14; Zelenkov 2013), stem from geographically more distant areas and the latter species is even younger than "G." pentelici.

Currently, most Miocene and Pliocene cranes are assigned to the taxon "Grus", but this classification mainly serves to distinguish these fossils from the morphologically distinct Balearicinae and the smaller species of Anthropoides. No fossil representative of the Gruidae has yet been subjected to a phylogenetic analysis including a wide range of extant species. Actually, it is likely that some of the fossil species branch early in the phylogeny of the Gruinae, but for the species from the Hammerschmiede, the limited data available on skull morphology do not allow firm phylogenetic conclusions.

In overall shape, the preserved portion of the skull of the fossil resembles the corresponding skull parts of Leucogeranus (Fig. 2d, 1), which has a similar skull size and relative beak length. As in Leucogeranus and Bugeranus (Fig. 2b, j), the skull of the Hammerschmiede crane has a low profile in lateral view, whereas in other Gruinae, the cranial vault 
is more elevated relative to the beak (Fig. 2). The dorsoventrally thick orbital rim of the frontal is present in most extant Gruinae except Bugeranus.

In some features, the Hammerschmiede fossil differs from all extant Gruidae. This is particularly true for the very wide internarial bar, but also applies to the absence of notches in the orbital rim for the supraorbital processes. With the limited anatomical data at hand, it is not possible to determine whether these differences indicate a plesiomorphic condition or are due to specializations of the Hammerschmiede crane. A wide internarial bear is absent in the Aramidae and Psophiidae, so that its occurrence in the Hammerschmiede crane may represent an autapomorphic specialization due to particular feeding habits.

Based on calibrated molecular data, Krajewski et al. (2010: Fig. 3) dated the origin of crown group Gruinae at about 12.5 million years ago. Given the only slightly younger age of the Hammerschmiede fossil, which is the earliest fossil record of the Gruinae, we consider it possible that the species is an early diverging representative of true cranes. A well-based phylogenetic assignment of the fossil is, however, only possibly once more skeletal elements have been found.

\section{Paleobiological implications}

All extant Gruidae occur in open habitats, but otherwise cranes have variable preferences concerning the nature of their environment. Whereas some smaller species (e.g., Balearica spp., Anthropoides virgo) live in dry grassland or savanna, all of the very large species inhabit wetlands (Archibald and Meine 1996). Habitat differences are also reflected by the length of the toes and beaks of cranes, with savanna species having shorter toes and beaks than species foraging in wetlands (Archibald and Meine 1996). The crane from the Hammerschmiede locality is not only one of the largest known species of the Gruidae, but it is also among those with the longest beak. Its very large size and long beak conform to an open freshwater paleohabitat, which prevailed at the Hammerschmiede locality (Böhme et al. 2019).

Very long beaks occur in only distantly related species of cranes, whereas the taxa Balearica and Anthropoides have notably shorter beaks than the Hammerschmiede crane and other extant Gruidae. Based on all current phylogenies, it is more parsimonious to assume that the stem species of the Gruinae already had a long beak and that the short beak of Anthropoides is a derived feature of the taxon.

Some Miocene and Pliocene species of the Gruinae were very large and reached the size of the largest extant cranes (Grus antigone and Bugeranus carunculatus). As detailed in the introduction, these large-sized cranes have been reported from the late Miocene to Pleistocene of Europe and Asia and from the Pliocene and Pleistocene of North and Central
America. Today, such large cranes no longer occur in Europe and the New World, and the reasons for their demise may have been both climatic and biotic.

Amongst endothermic vertebrates, species that live in cold climates tend to be larger than those occurring in subtropical or tropical areas (Meiri and Dayan 2003). However, within Gruidae this relation does not pertain, and most extant crane species that occur in northern latitudes are smaller than those in warm climates (an exception is the Siberian Crane, L. leucogeranus). The Hammerschmiede crane also lived in a subtropical environment, as did other large Miocene and Pliocene species.

Northcote (1982b) commented on the coexistence of large-sized cranes with the smaller extant Common Crane (Grus grus) in the Pleistocene of Europe. She hypothesized that very large cranes were more specialized in their dietary habits and lacked capabilities for long-distance migration, which made them more susceptible to extinction by environmental changes. The presence of very large cranes in the late Miocene of Europe may indicate that some Pleistocene insular forms, such as "Grus" melitensis and Grus cubensis, do not represent large-sized insular endemics, but are relics of formerly more widely distributed large-sized cranes. If these very large-sized cranes persisted under insular conditions non-climatic ecological factors, such as competition or predation, may have played a role in their extinction elsewhere in Europe and in the New World.

Acknowledgements Open Access funding provided by Projekt DEAL. We thank the Hammerschmiede excavation team from 2019 for their excellent work and tireless efforts. Thanks also to Sven Tränkner for taking the photographs and Adrian Tröscher for assisting in the transport of the fossil to Frankfurt. Reviews by Marco Pavia and Nikita Zelenkov improved the manuscript.

Open Access This article is licensed under a Creative Commons Attribution 4.0 International License, which permits use, sharing, adaptation, distribution and reproduction in any medium or format, as long as you give appropriate credit to the original author(s) and the source, provide a link to the Creative Commons licence, and indicate if changes were made. The images or other third party material in this article are included in the article's Creative Commons licence, unless indicated otherwise in a credit line to the material. If material is not included in the article's Creative Commons licence and your intended use is not permitted by statutory regulation or exceeds the permitted use, you will need to obtain permission directly from the copyright holder. To view a copy of this licence, visit http://creativecommons.org/licenses/by/4.0/.

\section{References}

Archibald GW, Meine CD (1996) Family Gruidae (cranes). In: del Hoyo J, Elliott A, Sargatal J (eds) Handbook of the birds of the world. Hoatzin to Auks, 3rd edn. Lynx Edicions, Barcelona, pp 60-89 
Böhme M, Aiglstorfer M, Uhl D, Kullmer O (2012) The antiquity of the Rhine River: stratigraphic coverage of the Dinotheriensande (Eppelsheim Formation) of the Mainz Basin (Germany). PLoS ONE 7(5):e36817

Böhme M, Spassov N, Ebner M, Geraads D, Hristova L, Kirscher U, Kötter S, Linnemann U, Prieto J, Roussiakis S, Theodorou G, Uhlig G, Winklhofer M (2017) Messinian age and savannah environment of the possible hominin Graecopithecus from Europe. PLoS ONE 12(5):e0177347

Böhme M, Spassov N, Fuss J, Tröscher A, Deane AS, Prieto J, Kirscher U, Lechner T, Begun DR (2019) A new Miocene ape and locomotion in the ancestor of great apes and humans. Nature 575:489-493

Brodkorb P (1963) Miocene birds from the Hawthorne Formation. Quart J Florida Acad Sci 26:159-167

Cheneval J (2000) L'avifaune de Sansan. Mém Mus Nat Hist Natur 183:321-388

Cheneval J, Escuillié F (1992) New data concerning Palaelodus ambiguus (Aves: Phoenicopteriformes: Palaelodidae): ecological and evolutionary interpretations. In: Campbell KE Jr (ed) Papers in Avian Paleontology honoring Pierce Brodkorb. Nat Hist Mus Los Angeles Cty, Sci Ser 36: 208-224

Cracraft J (1973) Systematics and evolution of the Gruiformes (Class Aves). 3. Phylogeny of the suborder Grues. Bull Am Mus Nat Hist 151:1-127

Depéret C (1887) Recherches sur la succession des faunes des vertébrés miocènes de la vallée du Rhône. Arch Mus Hist Nat Lyon 4:45-319

Emslie SD (1995) An early Irvingtonian avifauna from Leisey Shell Pit, Florida. Bull Florida Mus Nat Hist 37(1-10):299-344

Feduccia A, Voorhies MR (1992) Crowned cranes (Gruidae: Balearica) in the Miocene of Nebraska. In: Campbell KE Jr (ed) Papers in Avian Paleontology honoring Pierce Brodkorb. Nat Hist Mus Los Angeles Cty, Sci Ser, 36: 239-248

Fischer K, Stephan B (1971) Ein flugunfähiger Kranich (Grus cubensis n. sp.) aus dem Pleistozän von Kuba. Eine Osteologie der Familie der Kraniche (Gruidae). Wiss Z Humboldt-Univ Berl MathNaturwiss Reihe 20:541-592

Göhlich UB (2003) A new crane (Aves: Gruidae) from the Miocene of Germany. J Vertebr Paleontol 23:387-393

Grigorescu D, Kessler E (1977) The Middle Sarmatian avian fauna of South Dobrogea. Rev Roumaine Géol, Géophys Géogr 21:93-10

Kirscher U, Prieto J, Bachtadse V, Aziz HA, Doppler G, Hagmaier M, Böhme M (2016) A biochronologic tie-point for the base of the Tortonian stage in European terrestrial settings: Magnetostratigraphy of the topmost Upper Freshwater Molasse sediments of the North Alpine Foreland Basin in Bavaria (Germany). Newsl Stratigr 49:445-467

Krajewski C (1989) Phylogenetic relationships among cranes (Gruiformes: Gruidae) based on DNA hybridization. Auk 106:603-618

Krajewski C, Dickerman AW (1990) Bootstrap analysis of phylogenetic trees derived from DNA hybridization distances. Syst Zool 39:383-390

Krajewski C, Fetzner JW Jr (1994) Phylogeny of cranes (Gruiformes: Gruidae) based on cytochrome-b DNA sequences. Auk 111:351-365

Krajewski C, Sipiorski JT, Anderson FE (2010) Complete mitochondrial genome sequences and the phylogeny of cranes (Gruiformes: Gruidae). Auk 127:440-452

Kretzoi M (1957) Madármaradványok a Csákvari-faunából [Avian remains in the fauna of Csákvár]. Aquila 63-64:239-248

Lambrecht K (1933) Handbuch der Palaeornithologie. Gebrüder Borntraeger, Berlin

Lydekker R (1890) On the remains of some large extinct birds from the cavern-deposits of Malta. Proc Zool Soc London 28:403-411
Lydekker R (1891) Catalogue of the fossil birds in the British Museum (Natural History). British Museum (Natural History), London

Mayr G (2005) A chicken-sized crane precursor from the early Oligocene of France. Naturwiss 92:389-393

Mayr G (2009) Paleogene fossil birds. Springer, Heidelberg

Mayr G (2012) Parvigruidae (Aves, core-Gruiformes) from the early Oligocene of Belgium. Palaeobiodiv Palaeoenviron 93:77-89

Mayr G (2017) Avian evolution: The fossil record of birds and its paleobiological significance. Wiley-Blackwell, Chichester

Mayr G (2019) Hindlimb morphology of Palaeotis suggests palaeognathous affinities of the Geranoididae and other "crane-like" birds from the Eocene of the Northern Hemisphere. Acta Palaeontol Polon 64:669-678

Mayr G, Zvonok E (2011) Middle Eocene Pelagornithidae and Gaviiformes (Aves) from the Ukrainian Paratethys. Palaeontol 54:1347-1359

Mayr G, Lechner T, Böhme M (2020) The large-sized darter Anhinga pannonica (Aves, Anhingidae) from the late Miocene hominid Hammerschmiede locality in Southern Germany. PLoS ONE 15(5): 0232179

Meiri S, Dayan T (2003) On the validity of Bergmann's rule. J Biogeogr 30:331-351

Mlíkovský J (1998) A new barn owl (Aves: Strigidae) from the early Miocene of Germany, with comments on the fossil history of the Tytoninae. J Ornithol 139:247-261

Mlíkovský J (2002) Cenozoic birds of the world. Part 1: Europe. Ninox Press, Praha

Mourer-Chauviré C (2001) The systematic position of the genus Basityto Mlikovsky, 1998 (Aves: Gruiformes: Gruidae). Proc Biol Soc Wash 114:964-971

Mourer-Chauviré C, Balouet JC, Jehenne Y, Heintz É (1985) Une nouvelle espèce de grue, Grus afghana (Aves, Gruiformes), du Miocène supérieur de Molayan, Afghanistan. Bull Mus Nat Hist Natur, Sect C, Sci terre, paléontol, géol, minér 7:179-187

Northcote EM (1982a) The extinct Maltese crane Grus melitensis. Ibis $124: 76-80$

Northcote EM (1982b) Sympatry of common cranes, Grus grus with larger cranes in the last c. 125,000 years. Bull Br Ornithol Club 102:141-142

Northcote EM, Mourer-Chauviré C (1985) The distinction between the extinct Pleistocene European Crane, Grus primigenia, and the extant Asian Sarus Crane, G. antigone. Geobios 18:877-881

Northcote EM, Mourer-Chauviré C (1988) The extinct crane Grus primigenia Milne-Edwards in Majorca (Spain). Geobios 21:201-208

Olson SL (1985) The fossil record of birds. In: Farner DS, King JR, Parkes KC (eds) Avian biology, vol 8. Academic Press, New York, pp 79-238

Olson SL, Rasmussen PC (2001) Miocene and Pliocene birds from the Lee Creek Mine, North Carolina. Smithson Contrib Paleobiol 90:233-365

Pavia M, Insacco G (2013) The fossil bird associations from the early Middle Pleistocene of the Ragusa province (SE Sicily, Italy). Boll Soc Paleontol Ital 52:157-165

Portis A (1885) Contribuzioni alla ornitolitologia italiana. Mem Reale Accad Sci Torino 36:361-384

Seguí B (2002) A new genus of crane (Aves: Gruiformes) from the Late Tertiary of the Balearic Islands, Western Mediterranean. Ibis 144:411-422

Stewart JR (2007) An evolutionary study of some archaeologically significant avian taxa in the Quaternary of the Western Palaearctic. Brit Archaeol Rep Internat Ser 1653:1-272

Zelenkov NV (2013) New finds and revised taxa of Early Pliocene birds from Western Mongolia. In: Göhlich UB, Kroh A (eds) Paleornithological Research 2013 - Proceedings of the 8th International 
Meeting of the Society of Avian Paleontology and Evolution. Natural History Museum Vienna, Vienna, pp. 153-170

Zelenkov NV (2015) The fossil record and evolutionary history of cranes. In: Ilyashenko EI, Winter SV (eds) Cranes of Eurasia (biology, distribution, captive breeding). 5. Proceedings of the International Scientific Conference "Cranes of Eurasia: biology, conservation, management", Daursky Nature Reserve, Transbaikalia, Russia, 1-4 September 2015. Crane Working Group of Eurasia, Moscow and Nizhny Tsasuchei, Russia, pp. 88-90

Zelenkov NV, Kurochkin EN (2015) Class Aves. In: Vorobyeva EI, Kurochkin EN, Lopatin AV, Shishkin MA (eds) Fossil vertebrates of Russia and adjacent countries. Part 3, Fossil reptiles and birds. Geos, Moscow, pp. 86-290 [in Russian]

Publisher's Note Springer Nature remains neutral with regard to jurisdictional claims in published maps and institutional affiliations. 